\title{
ДВАДЦЯТИРІЧНИЙ МОНІТОРИНГ АНТИБІОТИКОРЕЗИСТЕНТНОСТІ СТАФІЛОКОКІВ, ІЗОЛЬОВАНИХ ВІД ХВОРИХ НА ГОСТРИЙ ЛЕЙКОЗ
}

\author{
Мельник О. А. \\ ДУ «Інститут гематології та трансфузіологї НАМН України», \\ Київ, Україна
}

\section{Резюме}

Вступ. 3'ясування характеру антибіотикорезистентності бактерій, особливо «проблемних», щуо виділяються від пацієнтів із онкогематологічними захворюваннями, є важливим для ефективного застосування емпіричної антибіотикоmepaniï.

Мета. Проаналізувати антибіотикорезистентність стафілококів - збудників інфекиійно-запальних ускладнень (ІЗУ), щзо були ізольовані з біотопів хворих на гострий лейкоз (ГЛ) впродовж 2002-2020 років.

Матеріали $\boldsymbol{i}$ методи. Досліджено резистентність до 60 антибіотичних препаратів (АБП) різних класифікаційних груп 118 штамів мікроорганізмів роду Staphylococcus: S. aureus (31), S. epidermidis (66), S. saprophyticus (11), S. sp. (10), ізольованих від хворих на гострий мієлоїдний лейкоз (ГМЛ) $і$ гострий лімфоїдний лейкоз (ГЛЛ) за 2002-2020 роки.

Результати. Спостерігали зростання стійкості від 0 до $100 \%$ культур S. еріdermidis, виділених від хворих на ГМЛ, до тетрациклінів, деяких цефалоспоринів, половини фторхінолонів і ертапенему та стовідсоткову резистентність до бензилпеніциліну, иефіксиму ц̌ цефподоксиму. Показано збільшення ізолятів метицилінрезистентних S. aureus (MRSA) від 40,0\% у 2002-2010 рр. до 63,6\% y 2011-2020 рр. Десятиріччя тому науковці визначали високий рівень стійкості S. aureus до пенічилінів, а як препарати вибору рекомендувалися аміноглікозиди й карбапенеми, щзо співпадає з результатами наших досліджень. $B$ останньому п'ятиріччі рекомендувалося використовувати глікопептидні АБП. Представлений у дослідженні ванкоміцин виявляв активність до 63,6\% клінічних итамів. Культури S. saprophyticus i Staphylococcus sp. були стовідсотково стійкими до бензилпеніциліну, оксациліну, окремих фторхінолонів $і$ аміноглікозидів, макролідів, лінкозамідів та иефалоспоринів. За 2002-2020 рр. у пацієнтів з ГЛЛ виділено 13 збудників ІЗУ стафілококової етіологї: 7 штамів S. epidermidis, 5 S. aureus, 1 - S. saprophyticus. Результати дослідження свідчать про мінливість антибіотикорезистентності итамів до різних АБП.

Висновки. Відзначено збільшення ізольованих від хворих на ГЛ MRSA від 40,0\% у 2001-2010 рр. до 63,6\% у 2011-2020 рр. Препаратами вибору були окремі 
аміноглікозиди, карбапенеми та рифампіщин. Встановлено наростання резистентності (до 71,4\%-100\%) видів S.epidermidis, S. saprophyticus i Staphylococcus sp. до окремих пеніцилінів, цефалоспоринів, аміноглікозидів та усіх представлених фторхінолонів. За міжнародною класифікацією визначено, щуо 51,0\% штамів ізольованих стафілококів відносяться до класу $M D R, 45,2 \%$ - до XDR, $3,8 \%-\partial o$ PDR.

Ключові слова: гострий лейкоз, стафілококи, антибіотики, резистентність, чутливість

Фінансування: дослідження не мало спонсорської підтримки.

\title{
THE ANTIBIOTIC RESISTANCE MONITORING OF STAPHYLOCOCCI ISOLATED FROM PATIENTS WITH ACUTE LEUKEMIA DURING 2002-2020 YEARS
}

\author{
Melnyk O. \\ SI «Institute of Haematology and Transfusiology of NAMS of Ukraine», \\ Kyiv, Ukraine
}

\begin{abstract}
Introduction. Determining the nature of antibiotic resistance of bacteria, especially "problematic», isolated from patients with oncohematological diseases, is important for the effective use of empirical antibiotic therapy.

Aim. To analyze the antibiotic resistance of staphylococci, pathogens of infectiousinflammatory complications (IIC), which were isolated from the biotopes of patients with acute leukemia $(A L)$ during 2002-2020 yy.

Materials and methods. Resistance to 60 antibiotic drugs (ABD) of different classification groups of 118 strains of microorganisms of the genus Staphylococcus was investigated: S. aureus (31), S. epidermidis (66), S. saprophyticus (11), S. sp. (10), isolated from patients with acute myeloid leukemia (AML) and acute lymphoid leukemia (ALL) for 2002-2020.

Results. There was an increase in resistance from 0 to $100 \%$ of S. epidermidis cultures isolated from AML patients to tetracyclines, some cephalosporins, half of fluoroquinolones, and ertapenem, and one hundred percent resistance to benzylpenicillin, cefixime, and cefpodoxime. An increase in methicillin-resistant $S$. aureus isolates (MRSA) from 40.0\% in 2002-2010 to 63.6\% in 2011-2020 has been shown. Decades ago, scientists determined a high level of resistance of $S$. aureus to penicillins, and as drugs of choice aminoglycosides and carbapenems were recommended, which coincides with the results of our studies Glycopeptide ABD has been recommended for the last five years. The vancomycin presented in the study showed activity in up to $63.6 \%$ of clinical strains. Cultures of S.saprophyticus and Staphylococcus sp. were one hundred percent resistant to benzylpenicillin, oxacillin, certain fluoroquinolones and aminoglycosides,
\end{abstract}


macrolides, lincosamides, and cephalosporins. During 2002-2020, 13 pathogens of Staphylococcal etiology were isolated from patients with GLL: 7 strains of S. epidermidis, 5 - S. aureus, $1-S$. saprophyticus. The results of the study indicate the variability of antibiotic resistance of strains to different $A B D$.

Conclusions. There was an increase in MRSA isolated from patients with AL from $40.0 \%$ in 2001-2010 to 63.6\% in 2011-2020. The ABD of choice were individual aminoglycosides, carbapenems, and rifampicin. Increasing resistance (up to $71.4 \%-100 \%$ of S. epidermidis, S. saprophyticus, and Staphylococcus sp. to individual penicillins, cephalosporins, aminoglycosides, and all present fluoroquinolones were established. According to the international classification, it is determined that $51.0 \%$ of strains of isolated staphylococci belong to the class $M D R, 45.2 \%$ - to XDR, 3.8\%-to PDR.

Keywords: acute leukemia, staphylococci, antibiotics, resistance, sensitivity.

\section{Вступ}

У структурі внутрішньолікарняних інфекцій значне місце, з точки зору антибактеріальної терапії, посідають «проблемні» мікроорганізми, які швидко набувають стійкості до більшості протимікробних препаратів, що використовуються у клінічних закладах. До фірмікутних «проблемних патогенів» віднесено метицилінрезистентні Staphylococcus aureus (MRSA), частота виділення яких перевищує $70 \%$ у стаціонарах всього світу [1]. Збільшення числа захворювань, спричинених полірезистентними фірмікутними збудниками, сприяє пошуку та впровадженню у клінічну практику нових АБП, у тому числі з анти- $M R S A$-активністю $[2,3]$.

Класифікація антибіотикорезистентності бактерій базується на їхній стійкості до певної кількості АБП усіх класифікаційних груп. Так, збудники з множинною лікарняною стійкістю $(M D R)$, тобто мультирезистентні - стійкі до одного АБП трьох та більше класів антибіотиків; зі значною (extensively) лікарняною стійкістю $(X D R)$ - резистентні до одного АБП у всіх класифікаційних групах, окрім одного чи двох класів антибіотиків; панрезистентні $(P D R)$ - стійкі до всіх відомих класів препаратів [4].

Вкрай важливою залишається проблема мікробної резистентності до антибіотиків, котрі застосовують у лікуванні пацієнтів із імунодепресією, що стає загрозою їхньому життю. Тому з'ясування характеру антибіотикорезистентності бактерій, які виділяються від хворих із онкогематологічними захворюваннями, є важливим для ефективного застосування емпіричної антибіотикотерапії та лікування пацієнтів, особливо у стані нейтропенії.

Мета. Проаналізувати антибіотикорезистентність стафілококів - збудників ІЗУ, що були ізольовані з біотопів хворих на ГЛ впродовж 20022020 років. 


\section{Матеріали та методи}

За період 2002-2020 pp. із біотопів верхніх дихальних шляхів, поверхні ран та при посівах крові на стерильність у хворих на лейкоз було ізольовано 798 штамів мікроорганізмів роду Staphylococcus, серед яких 364 культури було виділено від хворих на гострий мієлоїдний (ГМЛ) і гострий лімфоїдний лейкоз (ГЛЛ). Пацієнти перебували на лікуванні у відділенні захворювань системи крові ДУ «ІГТ НАМН України» на базі гематологічного відділення № 1 Київської міської клінічної лікарні № 9. Збудниками ІЗУ було визнано 118 штамів наступних видів: Staphylococcus aureus (31), S. epidermidis (66), S. saprophyticus (11), Staphylococcus sp. (10). Ідентифікацію ізольованих мікроорганізмів проводили за визначником Берджі на основі отриманих даних про морфолого-культуральні, фізіолого-біохімічні характеристики мікробних культур із використанням поживних середовищ: 5\% кров'яний агар на основі агару Columbia (BioMerieux, Франція), жовточно-сольовий агар та агар із манітом [5]. Чутливість етіологічних агентів до 60 АБП визначали за допомогою диско-дифузійного методу на агарі Мюлера-Хінтон (HiMedia Laboratories Pvt. Limited) [6]. Статистичну обробку представлених результатів проводили з використанням пакету Microsoft Office Excel 2007.

\section{Результати та їх обговорення}

Найбільшу групу хворих, у яких збудниками ІЗУ виявилися мікропорганізми виду S. epidermidis, склали пацієнти з ГМЛ. За результатами дослідження було встановлено, що впродовж чотирьох п'ятиріч спостерігалося помірне зростання резистентності (від 14,3 \% до 100 \%) ізолятів до наступних АБП різних класифікаційних груп: оксацилін, гентаміцин, цефалексин, цефотаксим, меропенем і левоміцетин (табл. 1).

Значно зросла кількість стійких штамів епідермальних стафілококів (від 11,1\% до 100 \%) по відношенню до групи тетрациклінів, що представлена двома АБП - тетрацикліном й доксицикліном, до цефалоспоринів III i IV поколінь, до половини антибіотиків із групи фторхінолонів та до ертапенему. Слід відмітити стовідсоткову резистентність S.epidermidis до бензилпеніциліну впродовж усього терміну дослідження та до цефіксиму й цефподоксиму - в останнє десятиріччя.

Аналіз антибіотикочутливості штамів S.epidermidis - чинників IЗУ у хворих на ГМЛ - показав, що препаратами вибору були у різні роки: карбеніцилін, азлоцилін і піперацилін; стрептоміцин, амікацин і нетилміцин; цефазолін, цефуроксим і цефамандол. Слід відзначити значне зростання чутливості епідермальних стафілококів до сульперазону від $0 \%$ 
до $80,0 \%$ в останне п'ятиріччя та факт стійкої чутливості ізольованих штамів до рифампіцину, ванкоміцину та фузидину, що коливалася від 75,0 \% до $100 \%$ за весь період дослідження.

За списком ВООЗ пріоритетних збудників захворювань мікроорганізми виду S. aureus знаходяться у 2 категорії пріоритетності з високим рівнем резистентності до метициліну, помірною чутливістю або стійкістю

Таблиця 1. Антибіотикорезистентність мікроорганізмів виду Staphylococcus epidermidis, ізольованих із біотопів хворих на ГМЛ

$$
(\mathbf{n}=\mathbf{5 9})
$$

\begin{tabular}{|c|c|c|c|c|c|c|c|c|c|}
\hline \multirow{3}{*}{$\begin{array}{c}\text { Групи } \\
\text { АБП }\end{array}$} & \multirow{3}{*}{ Назви АБП } & \multicolumn{8}{|c|}{ Кількість штамів мікроорганізмів по роках } \\
\hline & & \multicolumn{4}{|c|}{ стійкі, (\%) } & \multicolumn{4}{|c|}{ чутливі, (\%) } \\
\hline & & $\begin{array}{c}2002- \\
2006\end{array}$ & $\begin{array}{c}2007- \\
2011\end{array}$ & $\begin{array}{c}2012- \\
2016\end{array}$ & $\begin{array}{c}2017- \\
2020\end{array}$ & $\begin{array}{c}2002 \\
2006\end{array}$ & $\begin{array}{c}2007- \\
2011\end{array}$ & $\begin{array}{c}2012- \\
2016\end{array}$ & $\begin{array}{c}2017 \\
2020\end{array}$ \\
\hline \multirow{10}{*}{ 舅 } & Бензилпеніцилін & 100 & 100 & 96,6 & 100 & 0 & 0 & 3,4 & 0 \\
\hline & Оксацилін & 71,4 & 87,5 & 82,8 & 85,7 & 28,6 & 12,5 & 17,2 & 14,3 \\
\hline & Ампіцилін & 100 & 100 & 90,0 & 85,7 & 0 & 0 & 10,0 & 0 \\
\hline & Ампіокс & 100 & - & 60,0 & 57,1 & 0 & - & 20,0 & 28,6 \\
\hline & Карбеніцилін & 50,0 & 0 & 25,0 & - & 50,0 & 75,0 & 75,0 & - \\
\hline & Азлоцилін & 55,5 & - & 16,7 & - & 44,5 & - & 83,3 & - \\
\hline & Амоксицилін & 100 & - & 90,0 & 85,7 & 0 & - & 10,0 & 14,3 \\
\hline & Піперацилін & - & 66,6 & 33,3 & 0 & - & 33,4 & 66,7 & 80,0 \\
\hline & Ампісульбін & - & 66,7 & 50,0 & 57,1 & - & 33,4 & 43,8 & 14,3 \\
\hline & Амоксиклав: & - & - & 90,0 & 85,7 & - & - & 10,0 & 14,3 \\
\hline \multirow{8}{*}{ 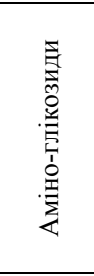 } & Стрептоміцин & 60,0 & 62,5 & 25,0 & 14,3 & 30,0 & 12,5 & 50,0 & 71,4 \\
\hline & Неоміцин & 20,0 & 33,3 & 25,0 & - & 50,0 & 66,7 & 75,0 & - \\
\hline & Канаміцин & 50,0 & 57,2 & 67,9 & 57,1 & 33,3 & 28,5 & 28,6 & 28,6 \\
\hline & Гентаміцин & 46,7 & 50,0 & 44,8 & 57,1 & 53,3 & 50,0 & 41,4 & 42,9 \\
\hline & Амікацин & 40,0 & 0 & 13,8 & 28,6 & 50,0 & 100 & 79,3 & 71,4 \\
\hline & Нетилміцин & 0 & 0 & - & - & 100 & 100 & - & - \\
\hline & Сізоміцин & - & 60,0 & 33,3 & - & - & 40,0 & 66,7 & - \\
\hline & Тоброміцин & - & 37,5 & 33,3 & - & - & 62,5 & 66,7 & - \\
\hline \multirow{2}{*}{ 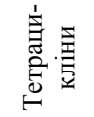 } & Тетрациклін & 40,0 & 75,0 & 27,6 & 71,4 & 40,0 & 12,5 & 62,1 & 28,6 \\
\hline & Доксіциклін & 30,8 & 85,7 & 21,4 & 71,4 & 38,5 & 14,3 & 64,3 & 28,6 \\
\hline \multirow{4}{*}{ 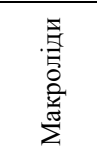 } & Еритроміцин & 80,0 & 87,5 & 55,2 & 57,1 & 20,0 & 12,5 & 31,0 & 14,3 \\
\hline & Рокситроміцин & 71,4 & 80,0 & 33,3 & - & 28,6 & 20,0 & 66,7 & - \\
\hline & Азітроміцин & - & 87,5 & 51,7 & 71,4 & - & 12,5 & 41,4 & 14,3 \\
\hline & Кларитроміцин & - & 83,3 & 58,8 & 71,4 & - & 16,7 & 35,3 & 28,6 \\
\hline
\end{tabular}


ГЕМАТОЛОГІЯ І ПЕРЕЛИВАННЯ КРОВІ: МІЖВІДОМЧИЙ ЗБІРНИК, 41, 2021

HEMATOLOGY \& BLOOD TRANSFUSION: INTERDEPARTAMENTAL COLLECTION, 41, 2021

Продовження табл. 1

\begin{tabular}{|c|c|c|c|c|c|c|c|c|c|}
\hline \multirow{3}{*}{$\begin{array}{c}\text { Групи } \\
\text { АБП }\end{array}$} & \multirow{3}{*}{ Назви АБП } & \multicolumn{8}{|c|}{ Кількість штамів мікроорганізмів по роках } \\
\hline & & \multicolumn{4}{|c|}{ стійкі, (\%) } & \multicolumn{4}{|c|}{ чутливі, (\%) } \\
\hline & & $\begin{array}{c}2002- \\
2006\end{array}$ & $\begin{array}{c}2007- \\
2011\end{array}$ & $\begin{array}{c}2012- \\
2016\end{array}$ & $\begin{array}{c}2017- \\
2020\end{array}$ & $\begin{array}{c}2002- \\
2006\end{array}$ & $\begin{array}{c}2007- \\
2011\end{array}$ & $\begin{array}{c}2012- \\
2016\end{array}$ & $\begin{array}{c}2017 \\
2020\end{array}$ \\
\hline \multirow{19}{*}{ 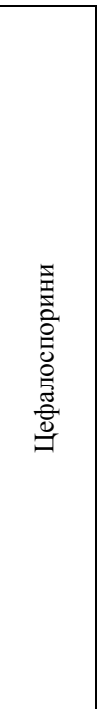 } & Цефазолін & 50,0 & 37,5 & 25,0 & 14,3 & 50,0 & 62,5 & 62,5 & 71,4 \\
\hline & \begin{tabular}{|l} 
Цефалексин \\
\end{tabular} & 40,0 & 50,0 & 56,2 & 57,1 & 40,0 & 50,0 & 25,0 & 14,3 \\
\hline & Цефалотин & - & 25,0 & 28,6 & - & - & 62,5 & 71,4 & - \\
\hline & Цефуроксим & 28,6 & 50,0 & 29,4 & 28,6 & 64,3 & 52,0 & 58,8 & 71,4 \\
\hline & Цефамандол & 14,3 & 14,3 & 16,7 & - & 85,7 & 85,7 & 83,3 & - \\
\hline & Цефаклор & - & 20,0 & 25,0 & - & - & 40,0 & 75,0 & - \\
\hline & Цефотаксим & 44,5 & 14,3 & 29,4 & 57,1 & 33,3 & 42,8 & 29,4 & 14,3 \\
\hline & Цефоперазон & 14,2 & 25,0 & 22,2 & 57,1 & 42,9 & 50,0 & 55,6 & 42,9 \\
\hline & Цефтазидим & 36,4 & 87,5 & 50,0 & 71,4 & 54,5 & 12,5 & 31,2 & 0 \\
\hline & \begin{tabular}{|l|} 
Цефтибутен \\
\end{tabular} & 60,0 & 100 & 25,0 & - & 40,0 & 0 & 50,0 & - \\
\hline & Сульперазон & 0 & 33,3 & 25,0 & 20,0 & 0 & 33,4 & 75,0 & 80,0 \\
\hline & Цефіксим & - & - & 100 & 100 & - & - & 0 & 0 \\
\hline & Цефподоксим & - & - & 100 & 100 & - & - & 0 & 0 \\
\hline & Цефтриаксон & - & 25,0 & 35,3 & 57,1 & - & 12,5 & 35,3 & 28,6 \\
\hline & Сульбактомакс & - & - & - & 80,0 & - & - & - & 20,0 \\
\hline & $\begin{array}{l}\text { Цефтазидим- } \\
\text { клавуланова } \\
\text { кислота }\end{array}$ & - & - & - & 80,0 & - & - & - & 20,0 \\
\hline & Цефтизоксим & - & - & - & 80,0 & - & - & - & 20,0 \\
\hline & Цефепим & 11,1 & 75,0 & 41,2 & 85,7 & 66,7 & 12,5 & 29,4 & 14,3 \\
\hline & Патентокс & - & - & 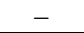 & 60,0 & - & - & - & 40,0 \\
\hline \multirow{7}{*}{ 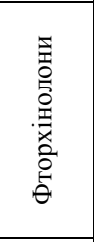 } & Пефлоксацин & 30,0 & 100 & 50,0 & - & 50.0 & 0 & 50,0 & - \\
\hline & Офлоксацин & 22,3 & 75,0 & 57,1 & 85,7 & 77,7 & 25,0 & 42,9 & 14,3 \\
\hline & Ципрофлоксацин & 50,0 & 100,0 & 60,7 & 85,7 & 16,7 & 0 & 32,1 & 14,3 \\
\hline & Норфлоксацин & 50,0 & 83,3 & 62,1 & 85,7 & 50,0 & 16,7 & 37,9 & 14,3 \\
\hline & Ломефлоксацин & - & 100 & 60,7 & 85,7 & - & 0 & 35,7 & 14,3 \\
\hline & \begin{tabular}{|l|} 
Левофлоксацин \\
\end{tabular} & - & 100 & 44,8 & 85,7 & - & 0 & 48,3 & 14,3 \\
\hline & Моксифлоксацин & - & 85,7 & 16,7 & - & - & 14,3 & 66,6 & - \\
\hline \multirow{2}{*}{ 总 } & Лінкоміцин & 58,3 & 71,4 & 51,7 & 42,8 & 33,4 & 28,6 & 41,4 & 42,9 \\
\hline & Кліндаміцин & 50,0 & 50,0 & 71,4 & 42,8 & 50,0 & 50,0 & 17,9 & 42,9 \\
\hline \multirow{3}{*}{ 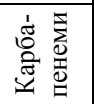 } & Іміпенем & 20,0 & 25,0 & 23,5 & 14,3 & 60,0 & 50,0 & 64,7 & 57,1 \\
\hline & Меропенем & 20,0 & 42,9 & 41,2 & 42,8 & 60,0 & 57,2 & 47,1 & 28,6 \\
\hline & Ертапенем & - & - & 33,4 & 100 & - & - & 58,3 & 0 \\
\hline \multirow{5}{*}{ 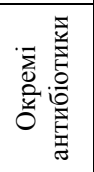 } & Левоміцетин & 37,5 & 71,4 & 44,4 & 57,1 & 50,0 & 28,6 & 51,9 & 42,9 \\
\hline & Ристоміцин & 25,0 & - & - & - & 25,0 & - & - & - \\
\hline & Фузидин & 0 & 0 & 0 & - & 100 & 85,7 & 80,0 & - \\
\hline & Ванкоміцин & - & 0 & 24,1 & 14,3 & - & 100 & 69,0 & 85,7 \\
\hline & Рифампіцин & 15,4 & 12,5 & 10,3 & 0 & 84,6 & 75,0 & 82,8 & 100 \\
\hline
\end{tabular}


до ванкоміцину [2]. П’ятиріччя тому розповсюдженість інфекцій, викликаних MRSA, мала такі статистичні та географічні особливості: в скандинавських країнах та Нідерландах - $5 \%$, Німеччині - 7 \%, Греції, Італії, Португалії, Франції - 36-57 \%, Китаї та Японії - 60 \%, Російській Федерації - 27-73 \%, в Україні ця цифра складала 31,4 \% [7].

Проведений нами багаторічний моніторинг антибіотикорезистентності S. aureus показав збільшення ізолятів MRSA, які виявилися чинниками ІЗУ у хворих на ГМЛ, від 40,0\% у 2002-2010 рр. до 63,6 \% у 20112020 pр. (табл. 2).

\section{Таблиця 2. Антибіотикорезистентність мікроорганізмів виду}

Staphylococcus aureus, ізольованих із біотопів хворих на ГМЛ (n=26)

\begin{tabular}{|c|c|c|c|c|c|}
\hline \multirow{3}{*}{$\begin{array}{c}\text { Групи } \\
\text { АБП }\end{array}$} & \multirow{3}{*}{ Назви АБП } & \multicolumn{4}{|c|}{ Кількість штамів мікроорганізмів } \\
\hline & & \multicolumn{2}{|c|}{ стійкі, (\%) } & \multicolumn{2}{|c|}{ чутливі, (\%) } \\
\hline & & $\begin{array}{c}2002- \\
2010\end{array}$ & $\begin{array}{c}2011- \\
2020\end{array}$ & $\begin{array}{c}2002- \\
2010\end{array}$ & $\begin{array}{c}2011- \\
2020\end{array}$ \\
\hline \multirow{10}{*}{ Пеніциліни } & Бензилпеніцилін & 100 & 81,8 & 0 & 18,2 \\
\hline & Оксацилін & 40,0 & 63,6 & 40,0 & 27,3 \\
\hline & Ампіцилін & 100 & 50.0 & 0 & 50,0 \\
\hline & Ампіокс & 100 & 50,0 & 0 & 50,0 \\
\hline & Карбеніцилін & 60,0 & 0 & 0 & 100,0 \\
\hline & Азлоцилін & 66,7 & 0 & 33,3 & 100 \\
\hline & Амоксицилін & 100 & 50,0 & 0 & 50,0 \\
\hline & Піперацилін & 100 & 0 & 0 & 100 \\
\hline & Ампісульбін & 100 & 20,0 & 0 & 60,0 \\
\hline & Амоксиклав & - & 33.3 & - & 66,7 \\
\hline \multirow{8}{*}{$\begin{array}{c}\text { Аміноглі- } \\
\text { козиди }\end{array}$} & Стрептоміцин & 75,0 & 50,0 & 25,0 & 37,5 \\
\hline & Неоміцин & 20,0 & 0 & 60,0 & 100 \\
\hline & Канаміцин & 33,3 & 36,4 & 33,4 & 54,5 \\
\hline & Гентаміцин & 23,1 & 27,3 & 69,2 & 72,7 \\
\hline & Амікацин & 33,3 & 18,2 & 50,0 & 72,7 \\
\hline & Нетилміцин & 12,5 & - & 75.0 & - \\
\hline & Сізоміцин & 0 & 0 & 100 & 100 \\
\hline & Тоброміцин & 0 & 0 & 100 & 100 \\
\hline \multirow{2}{*}{$\begin{array}{c}\text { Тетра- } \\
\text { цикліни }\end{array}$} & Тетрациклін & 12,5 & 36,4 & 37,5 & 45,5 \\
\hline & Доксіциклін & 15,4 & 36,4 & 46,1 & 54,5 \\
\hline
\end{tabular}


ГЕМАТОЛОГІЯ І ПЕРЕЛИВАННЯ КРОВІ: МІЖВІДОМЧИЙ ЗБІРНИК, 41, 2021 HEMATOLOGY \& BLOOD TRANSFUSION: INTERDEPARTAMENTAL COLLECTION, 41, 2021

Продовження табл. 2

\begin{tabular}{|c|c|c|c|c|c|}
\hline \multirow{3}{*}{$\begin{array}{c}\text { Групи } \\
\text { АБП }\end{array}$} & \multirow{3}{*}{ Назви АБП } & \multicolumn{4}{|c|}{ Кількість штамів мікроорганізмів } \\
\hline & & \multicolumn{2}{|c|}{ стійкі, (\%) } & \multicolumn{2}{|c|}{ чутливі, (\%) } \\
\hline & & $\begin{array}{c}2002- \\
2010\end{array}$ & $\begin{array}{c}2011- \\
2020\end{array}$ & $\begin{array}{c}2002- \\
2010\end{array}$ & $\begin{array}{c}2011- \\
2020\end{array}$ \\
\hline \multirow{4}{*}{ Макроліди } & Еритроміцин & 46,2 & 72,7 & 30,7 & 9,1 \\
\hline & Рокситроміцин & 37,5 & 0 & 62,5 & 75,0 \\
\hline & Азітроміцин & 33,3 & 72,7 & 33,3 & 18,2 \\
\hline & Кларитроміцин & 100 & 37,5 & 0 & 62,5 \\
\hline \multirow{14}{*}{$\begin{array}{l}\text { Цефало- } \\
\text { спорини }\end{array}$} & Цефазолін & 0 & 0 & 100 & 100 \\
\hline & Цефалексин & 37,5 & 12,5 & 62,5 & 50,0 \\
\hline & Цефуроксим & 10,0 & 12,5 & 80,0 & 87,5 \\
\hline & Цефамандол & 42,9 & 0 & 57,1 & 75,0 \\
\hline & Цефаклор & 0 & 0 & 100 & 100 \\
\hline & Цефотаксим & 80,0 & 12,5 & 20,0 & 37.5 \\
\hline & Цефоперазон & 40.0 & 0 & 50,0 & 100 \\
\hline & Цефтазидим & 30,0 & 37,5 & 40,0 & 37,5 \\
\hline & Сульперазон & - & 0 & - & 100 \\
\hline & Цефіксим & - & 66,7 & - & 0 \\
\hline & Цефподоксим & - & 100 & - & 0 \\
\hline & Цефтриаксон & 0 & 12,5 & 100 & 37,5 \\
\hline & Сульбактомакс & 0 & 16,7 & 100 & 50,0 \\
\hline & Цефепим & 46,2 & 14,3 & 53,8 & 71,4 \\
\hline \multirow{7}{*}{$\begin{array}{c}\text { Фторхіно- } \\
\text { лони }\end{array}$} & Пефлоксацин & 41,7 & 0 & 50,0 & 50,0 \\
\hline & Офлоксацин & 33,3 & 18,2 & 66,7 & 81,8 \\
\hline & Ципрофлоксацин & 66,7 & 50,0 & 33,3 & 40,0 \\
\hline & Норфлоксацин & 16,7 & 45,5 & 33,3 & 36,4 \\
\hline & Ломефлоксацин & 0 & 54,5 & 66,7 & 27,3 \\
\hline & Левофлоксацин & - & 36,4 & - & 45,5 \\
\hline & Моксифлоксацин & - & 50,0 & - & 50,0 \\
\hline \multirow{2}{*}{ Лінкозаміди } & Лінкоміцин & 23,1 & 45,5 & 61,5 & 9,0 \\
\hline & Кліндаміцин & 14,3 & 54,5 & 71,4 & 36,4 \\
\hline \multirow{2}{*}{ Карбапенеми } & Іміпенем & 0 & 0 & 100 & 100 \\
\hline & Меропенем & 0 & 0 & 100 & 100 \\
\hline \multirow{5}{*}{$\begin{array}{c}\text { Окремі } \\
\text { антибіотики }\end{array}$} & Левоміцетин & 18,2 & 54,5 & 63,6 & 27,3 \\
\hline & Ристоміцин & 100 & - & 0 & - \\
\hline & Фузидин & 18,2 & 0 & 72,4 & 75,0 \\
\hline & Ванкоміцин & 0 & 27,3 & 100 & 63,6 \\
\hline & Рифампіцин & 8,3 & 0 & 91,7 & 100 \\
\hline
\end{tabular}


Десять років тому науковці визначали високий рівень резистентності клінічних штамів S.aureus до великого спектра АБП пеніцилінового ряду, що співпадає з результатами наших досліджень. Пропонувалося у якості препаратів вибору при лікуванні інфекційно-запальних уражень, викликаних метицилін- та ванкоміцин-резистентними штамами S. aureus використовувати карбапенеми, фторхінолоніли II-IV поколінь, деякі макроліди й аміноглікозиди [8]. За результатами наших досліджень із вищевказаного переліку АБП високою активністю щодо MRSA характеризувалися окремі аміноглікозиди і карбапенеми.

В останньому п'ятиріччі, за даними літературних джерел, у разі виявлення метицилінорезистентності у штамів S.aureus рекомендувалося використовувати як препарати вибору глікопептидні АБП [7]. Представлений у дослідженні ванкоміцин із групи глікопептидів виявляв активність до 63,6 \% штамів - збудників ІЗУ у хворих на ГЛ. Слід зауважити, що протягом двох десятиріч чутливість клінічних штамів S. aureus до рифампіцину коливалась у межах від 91,7 \% до 100 \%.

За багаторічний період дослідження від хворих на ГМЛ було виділено по 10 штамів - збудниками ІЗУ стафілококової етіології інших видів S. saprophyticus i Staphylococcus sp. (табл. 3).

Таблиця 3. Антибіотикорезистентність мікроорганізмів виду S. saprophyticus i Staphylococcus sp., ізольованих від хворих на ГМЛ $(\mathbf{n}=\mathbf{2 0})$

\begin{tabular}{|l|c|c|c|}
\hline \multirow{2}{*}{ Групи АБП } & \multicolumn{4}{|c|}{ Кількість штамів мікроорганізмів за 2002-2020 рp., (\%) } \\
\cline { 2 - 4 } & $\begin{array}{c}\text { стійкі } \\
\text { (min-max) }\end{array}$ & $\begin{array}{c}\text { проміжні } \\
\text { (min-max) }\end{array}$ & $\begin{array}{c}\text { чутливі } \\
\text { (min-max) }\end{array}$ \\
\hline Пеніциліни & $50,0-100$ & $0-50,0$ & $0-50,0$ \\
\hline Аміноглікозиди & $0-100$ & $0-50,0$ & $0-100$ \\
\hline Тетрацикліни & $0-60,0$ & $0-20,0$ & $40,0-80,0$ \\
\hline Макроліди & $60,0-100$ & $0-33,3$ & $0-25,0$ \\
\hline Цефалоспорини & $0-100$ & $0-60,0$ & $0-75,0$ \\
\hline Фторхінолони & $50,0-100,0$ & $0-50,0$ & $0-33,3$ \\
\hline Лінкозаміди & $0-100$ & $0-33,3$ & $0-66,7$ \\
\hline Карбапенеми & $0-100$ & $0-50,0$ & $50,0-100$ \\
\hline \multicolumn{5}{|c|}{ Окремі антибіотики } \\
\hline Левоміцетин & $0-100$ & $0-50,0$ & $0-50,0$ \\
\hline Ристоміцин & $50,0-100$ & 0 & $0-100$ \\
\hline Фузидин & $20-33,3$ & $0-20,0$ & $60,0-66,7$ \\
\hline Ванкоміцин & $0-83,3$ & 0 & $16,7-80,0$ \\
\hline Рифампіцин & $16,7-40,0$ & 0 & $60,0-100$ \\
\hline
\end{tabular}


Аналізуючи отримані результати встановлено: дані ізоляти мали стійку резистентність (100\%) до половини фторхінолонів й окремих АБП із груп аміноглікозидів, макролідів, лінкозамідів і цефалоспоринів у різні періоди спостереження та до бензилпеніциліну й оксациліну впродовж останніх двадцяти років.

Препаратами вибору для мікроорганізмів виду S. saprophyticus стали тетрацикліни, цефамандол і цефепім, іміпенем і ванкоміцин. Усі ізоляти сапрофітного стафілококу у другому десятиріччі проявляли стовідсоткову чутливість до стрептоміцину. Для збудників Staphylococcus sp. Препаратами вибору були меропенем у першому десятиріччі та рифампіцин протягом 2011-2020 років.

За двадцять років дослідження із біотопів хворих на ГЛЛ було ізольовано 13 культур стафілококів - збудників IЗУ, серед яких 7 штамів ідентифікували як S. epidermidis, 5 - S. aureus, 1 штам - S. saprophyticus. У зв'язку з незначною кількістю культур аналізу щодо динаміки змін стійкості до АБП впродовж часу спостереження не було проведено. Проте, результати їхньої антибіотикорезистентності, що наведені у таблиці 4 , свідчать про мінливість впливу на дані штами АБП різних класифікаційних груп. Так, половина культур S. epidermidis характеризувалася стовідсотковою стійкістю до деяких пеніцилінів і низькою резистентністю до аміноглікозидів (0-33,3 \%) та лінкозамідів (0-14,3 \%). Натомість, по відношенню до карбапенемів усі ізоляти були чутливими на $66,7-80,0$ \%, а до фузидину й рифампіцину проявляли стовідсоткову чутливість.

Чотири штами S. aureus, виділені від хворих на ГЛЛ, виявилися стовідсотково стійкими до групи пеніцилінів (окрім азлоциліну), до цефотаксиму та проявляли чутливість по відношенню до цефалоспоринів (окрім цефотаксиму й цефтазидиму), фузидину й рифампіцину (табл.4).

Відповідно до критеріїв міжнародної класифікації антибіотичної резистентності серед 104 збудників ІЗУ стафілококової етіології, що були ізольовані з біотопів хворих на ГМЛ і ГЛЛ упродовж 2002-2020 років, виявлено 51,0 \% мультирезистентних штамів класу MDR; 45,2 \% ізолятів віднесено до групи XDR i 3,8 \% культур характеризувалися як PDR, тобто були стійкими до всіх відомих класів АБП. Чотирнадцять ізольованих штамів не було класифіковано через їх невідповідність даним критеріям.

Отже, результати проведеного багаторічного моніторингу антибіотикної резистентності фірмікутів роду Staphylococcus, що виявилися чинниками ІЗУ у хворих на ГЛ, свідчать про наростання їх стійкості до АБП різних класифікаційних груп, у тому числі й до препаратів останніх поколінь. Тому з метою проведення адекватної антибіотикотерапії у 
хворих на лейкоз доцільним є застосування АБП за індивідуально визначеною антибіотикограмою.

Таблиця 4. Антибіотикорезистентність мікроорганізмів виду

S. epidermidis та S. aureus, ізольованих від хворих на ГЛЛ (n=13)

\begin{tabular}{|l|c|c|}
\hline \multirow{2}{*}{ Групи АБП } & \multicolumn{2}{|c|}{ Кількість штамів мікроорганізмів за 2002-2020 рp. } \\
\cline { 2 - 3 } & $\begin{array}{c}\text { стійкі, (\%) } \\
\text { (min-max) }\end{array}$ & $\begin{array}{c}\text { чутливi, (\%) } \\
\text { (min-max) }\end{array}$ \\
\hline Пеніциліни & $\begin{array}{c}25,0-100 \text { (карбеніцилін - 0, } \\
\text { S. aureus - азлоцилін - 50,0) }\end{array}$ & $0-60,0$ \\
\hline Аміноглікозиди & $0-33,3$ & $50,0-100$ \\
\hline Тетрацикліни & $0-66,7$ & $33,3-50,0$ \\
\hline Макроліди & $0-50,0$ & $25,0-50,0$ \\
\hline Цефалоспорини & $\begin{array}{c}0-66,7 \\
\text { (S. aureus - цефотаксим - 100) }\end{array}$ & $25,0-100$ \\
\hline Фторхінолони & $0-80,0$ & $20,0-50,0$ \\
\hline Лінкозаміди & $0-25,0$ & $71,4-100$ \\
\hline Карбапенеми & 0 & $66,7-80,0$ \\
\hline \multicolumn{2}{|c|}{ Окремі антибіотики } \\
\hline Левоміцетин & 33,3 & 66,7 \\
\hline Фузидин & (S. aureus - 25,0) & 100 \\
\hline Ванкоміцин & 0 & 66,7 \\
\hline Рифампіцин & 33,3 & 100 \\
\hline
\end{tabular}

\section{Висновки}

1. За період 2002-2020 років із біотопів хворих на лейкемію ізольовано 798 мікроорганізмів роду Staphylococcus, серед яких 118 штамів було визнано збудниками ІЗУ у пацієнтів із ГМЛ та ГЛЛ.

2. Відзначено збільшення ізольованих від хворих на ГЛ метицилінрезистентних S. aureus від 40,0\% у 2001-2010 pр. до 63,6\% у 20112020 pр. Препаратами вибору впродовж усього терміну спостереження були окремі аміноглікозиди, карбапенеми та рифампіцин.

3. Встановлено наростання резистентності (до 71,4\%-100\%) видів S. epidermidis, S. saprophyticus i Staphylococcus sp. до окремих пеніцилінів, цефалоспоринів, аміноглікозидів та усіх представлених фторхінолонів.

4. За міжнародною класифікацією антибіотикорезистентності бактерій визначено, що 51,0\% штамів ізольованих стафілококів відносяться до класу MDR, 45,2 \% - до XDR, 3,8 \% - до PDR. 


\section{Література}

1. Orsini J, Mainardi C, Muzylo E, Karki N, Cohen N, Sakoula G. Microbiological profile of organisms causing bloodstream infection in critically ill patients. J Clin Med Res. 2012; 4(6):371-7.

2. Список ВОЗ приоритетных возбудителей заболеваний для НИОКР в области создания новых антибиотиков. 27 февраля 2017 г. Выпуск новостей Женева:

https://www.who.int/ru/news-room/ detail/27-02-2017-who-publishes-

list-of-bacteria-for-which-newantibiotics-are-urgently-needed.

3. Черненькая Т.В., Годков М.А. «Проблемные» полирезистентные бактерии - возбудители внутрибольничных инфекций у пациентов в критических состояниях (обзор литературы). Журнал им. Н.В. Склифосовского Неотложная медицинская помощь. 2015; 3:30-5.

4. Vivas R, Barbosa A, Dolabela S, Jain S. Multidrug-Resistant Bacteria and Alternative Methods to Control Them: An Overview. Microb Drug Resist Jul/Aug 2019;25(6):890-908. doi: 10.1089/mdr.2018.0319.

Epub 2019 Feb 27.

5. Определитель бактерий Берджи / Под ред. Дж. Хоулта, Н. Крига, П. Снита и др. пер. с англ. Г.А. Заварзина. М. : Мир,1997. $800 \mathrm{c}$.

6. Про затвердження методичних вказівок «Визначення чутливості мікроорганізмів до антибактеріальних препаратів» / Наказ МО3 України № 167 від 05.04.2007 р. K., 2007.113 c.

\section{References}

1. Orsini J., Mainardi C., Muzylo E., Karki N., Cohen N., Sakoula G. Microbiological profile of organisms causing bloodstream infection in critically ill patients. J Clin Med Res: 2012: 4(6):371-7.

2. Spisok VOZ prioritetnykh vozbuditeley zabolevaniy dlya NIOKR v oblasti sozdaniya novykh antibiotikov $27 \mathrm{fev}$ ralya 2017 g. Vypusk novostey Zheneva:

https://www.who.int/ru/news-room/ detail/27-02-2017-who-publishes-listof-bacteria-for-which-new-antibioticsare-urgently-needed.

3. Chernenkaya T.V., Godkov M.A. «Problemnye» polirezistentnye bakterii - vozbuditeli vnutribol'nichnykh infektsiy $\mathrm{u}$ patsientov $\mathrm{v}$ kriticheskikh sostoyaniyakh (obzor literatury) Zhurnal im N.V. Sklifosovskogo Neotlozhnaya meditsinskaya pomoshch'. 2015; 3: $30-5$.

4. Vivas R, Barbosa A, Dolabela S, Jain S. Multidrug-Resistant Bacteria and Alternative Methods to Control Them: An Overview. Microb Drug Resist Jul/Aug 2019;25(6):890-908. doi: 10.1089/mdr.2018.0319. Epub 2019 Feb 27.

5. Dzh. Khoult, N. Krig, P. Snit (1997). Opredelitel bakterii Berdzhi. [The Berjee bacteria determinant] Moskow: Mir, 800 p.

6. Pro zatverdzhennia metodychnykh vkazivok «Vyznachennia chutlyvosti mikroorhanizmiv do antybakterialnykh preparative» / Nakaz MOZ Ukrainy № 167 vid 05.04.2007 r. K., 2007. 113 s. (in Ukrainian). 
7. Гаркавенко Т.О., Козицька Т.Г. Механізм резистентності та методи виявлення метицилінрезистентного стафілокока (MRSA) (Оглядова стаття). Ветеринарна біотехнологія. 2016;28:42-54.

8. Назарчук О.А., Назарчук Г.Г., Палій Д.В., Сухляк В.В. Чутливість клінічних штамів Staphylococcus aureus до антибактеріальних препаратів. Український медичний часопис. 2012;3(89): 26-31

Надійшла: 16.08.2021

Контакти: igtmicrob@ukr.net
7. Harkavenko T.O., Kozytska T.H. Mekhanizm rezystentnosti ta metody vyiavlennia metytsylinrezystentnoho stafilokoka (MRSA) (Ohliadova stattia). Veterynarna biotekhnolohiia. 2016; 28: 42-54. (in Ukrainian).

8. Nazarchuk O.A., Nazarchuk H.H., Palii D.V., Sukhliak V.V. Chutlyvist klinichnykh shtamiv Staphylococcus aureus do antybakterialnykh preparativ. Ukrainskyi medychnyi chasopys. 2012; 3(89): 26-31 (in Ukrainian). 